ELECTRONIC LETTER

\title{
Position effect on PLP1 may cause a subset of Pelizaeus- Merzbacher disease symptoms
}

\author{
N Muncke*, B S Wogatzky*, M Breuning, E A Sistermans, V Endris, M Ross, D Vetrie, C E Catsman- \\ Berrevoets, G Rappold
}

J Med Genet 2004;41:e121 (http://www.jmedgenet.com/cgi/content/full/41/12/e121). doi: 10.1136/jmg.2004.019141

$P$ lizaeus-Merzbacher disease (PMD, MIM 312080) is an $\mathrm{X}$ linked disorder characterised by dysmyelination of the central nervous system (CNS) ${ }^{12}$ (see review by Koeppen and Robitaille ${ }^{3}$. Two main forms of the disease, a connatal and a classical type, are recognised. The connatal type has a severe course with feeding problems, progressive pyramidal and extrapyramidal symptoms, laryngeal stridor, microcephaly, very little development, and a natural disease duration of 5-7 years. The classical type evolves into spastic tetraparesis, ataxia, choreoathetoid movements of the limbs, and cognitive impairment. The disorder progresses at a variable rate and some children are able to sit with support or occasionally walk, before slow regression sets in. Seizures may occur in both types (table 1). PMD has been shown to be caused by mutations in the proteolipid protein ( $P L P 1)$ gene, encoding the major myelin component in the CNS. ${ }^{45}$ PLPl is also involved in the aetiology of $X$ linked spastic paraplegia (SPG2), which manifests as progressive weakness and spasticity of the lower extremities with or without CNS involvement. ${ }^{67}$ Mutations causing PMD can be divided into two main categories: duplications of PLP1, which account for the majority of cases $(60-70 \%)$, and sequence variations within the gene $(15-20 \%){ }^{8}$ The remaining $10-20 \%$ of patients have no detectable mutation within PLPl, suggesting that mutations in regulatory regions or other gene loci can also cause PMD. Disease severity ranges from severe connatal PMD to mild PMD/SPG2 with an intermediate classical form. Patients with PLPI duplications have a predominantly milder classical phenotype, whereas patients with missense mutations show a much wider spectrum, ranging from more severely affected to SPG $2 .{ }^{8}$ Duplication sizes vary significantly. ${ }^{90}$ Absence of the PLP protein caused either by gene deletions or null mutations causes a specific mild form of PMD that includes length dependent axonal degeneration..$^{11} 12$

We have mapped and analysed the chromosomal breakpoint regions of a male patient with an $\operatorname{inv}(X)(p 22.3 ; q 22)$ suffering from a subset of PMD symptoms including moderate mental retardation (Wechsler Intelligence Scale for Children, revised Dutch edition (WISC-RN) IQ 55-59) and cerebellar ataxia associated with dysmyelination. The breakage event in Xq22 affects GLRA4, a putative pseudogene of the glycine receptor gene family, approximately $70 \mathrm{~kb}$ apart from the PLPl gene. We discuss the fact that a position effect on PLPI, rather than a duplication or missense mutation, is considered to be causative for a subset of clinical PMD symptoms.

\section{METHODS}

Fluorescence in situ hybridisation (FISH) analysis Biotinylated cosmid, PAC, or YAC DNA was hybridised to metaphase chromosomes of lymphocytes of patients as described. ${ }^{13}$ Hybridisation signals were detected via avidin conjugated FITC. Chromosomes were counterstained with

\section{Key points}

- Pelizaeus-Merzbacher disease (PMD, MIM 312080 ) is an $\mathrm{X}$ linked recessive dysmyelination disorder of the central nervous system caused by mutations in the proteolipid protein gene (PLP1). The clinical spectrum varies widely. In the two main forms of the disease, the classical and connatal types, onset of symptoms is in the first few months of life with nystagmus and hypotonia, but rate of progression and severity of the clinical picture differ.

- We report on a patient with an inverted X chromosome displaying a subset of PMD symptoms including a PMD typical dysmyelination pattern. Physical mapping revealed that the $X_{q} 22$ breakpoint, residing in close vicinity to the $P L P 1$ gene, interrupts $G L R A 4$, a putative pseudogene similar to glycine receptor alpha-2 chain. Mutation screening of GLRA4 in patients with ataxia (with or without dysmyelination) and in patients with spastic paraplegia failed to identify patient specific mutations.

- Therefore, we do not consider GLRA4 to be involved in the phenotype, but suggest that a position effect on PLP1 ranging over $70 \mathrm{~kb}$ is responsible for the pathogenesis. This is the first case where a position effect on PLPI rather than a duplication or missense mutation is considered to be causative for a subset of PMD symptoms.

DAPI. Images of FITC and DAPI stained chromosomes were taken separately by using a cooled charge coupled device camera system (Photometrics, Tucson, AZ, USA). A Macintosh Quadra 900 was used for camera control and digital image acquisition in "TIFF" format using the software package Nu200 2.0 (Photometrics). Separate grey scale fluorescence images were recorded for each fluorochrome. Images were overlaid electronically and further processed with Adobe Photoshop software.

Polymerase chain reaction (PCR) amplification

All PCR amplifications were carried out in a final volume of $50 \mu$ with 100-200 ng template, 20 pmol of each primer, $200 \mu \mathrm{M}$ dNTPs (MBI Fermentas, Vilnias, Lithuania), $1.5 \mathrm{mM}$ $\mathrm{MgCl}_{2}, 75 \mathrm{mM}$ Tris-HCl pH 9.0, $20 \mathrm{mM}\left(\mathrm{NH}_{4}\right)_{2} \mathrm{SO}_{4}, 0.01 \%$

Abbreviations: CNS, central nervous system; FISH, fluorescence in situ hybridisation; PMD, Pelizaeus-Merzbacher disease; SPG2, X linked spastic paraplegia; SSCP, single strand conformation polymorphism; WISC-RN, Wechsler Intelligence Scale for Children, revised Dutch edition 
Tween 20, and 2 U of Goldstar DNA Polymerase (Eurogentec, Seraing, Belgium). Cycling was carried out in a GeneE Thermocycler (Techne, Burkhardtsdorf, Germany) under the following conditions: $94^{\circ} \mathrm{C}$ for $3 \mathrm{~min} ; 94^{\circ} \mathrm{C}$ for $20 \mathrm{~s}, \mathrm{~T}_{\mathrm{A}}$ for $20 \mathrm{~s}, 72^{\circ} \mathrm{C}$ for $20 \mathrm{~s}$ (for 38 cycles), and a final extension of $5 \mathrm{~min}$ at $72^{\circ} \mathrm{C}\left(\mathrm{T}_{\mathrm{A}}\right.$ indicates annealing temperature).

\section{Single strand conformation polymorphism (SSCP) analysis}

SSCP analysis was performed on amplified genomic DNA from patients as described. ${ }^{14}$ The PCR products $(1-5 \mu \mathrm{l})$ were mixed with $5 \mu \mathrm{l}$ of denaturation solution containing $95 \%$ formamide and $10 \mathrm{mM}$ EDTA pH 8.0 and denatured at $95^{\circ} \mathrm{C}$ for $10 \mathrm{~min}$. Samples were immediately chilled on ice and loaded on a $10 \%$ polyacrylamide gel (acrylamide:bisacrylamide $=37.5: 1$ and 29:1; multi slot gel, TGGE base, Qiagen, Venlo, The Netherlands) containing $2 \%$ glycerol and $1 \times$ TBE. Gels were run at $15^{\circ} \mathrm{C}$, in $1 \times \mathrm{TBE}$, at $500 \mathrm{~V}$ for $3-5 \mathrm{~h}$ and silver stained as described in the TGGE handbook (Qiagen).

\section{Cloning and sequencing of PCR products}

PCR products were cloned into the pCR2.1-TOPO vector (Invitrogen Carlsbad, CA, USA). The clones were sequenced with Cy5 labelled vector primers M13, universal and reverse, by the cycle sequencing method described by the manufacturer (ThermoSequenase Kit, Amersham; merged with General Electrics Healthcare, Slough, UK), and analysed on an ALF express automated sequencer (Pharmacia; merged with General Electrics Healthcare, Slough, UK).

\section{RESULTS}

\section{Clinical report}

Investigations were carried out on a male patient from the Erasmus MC/Sophia Children's Hospital and his unaffected mother. The pregnancy, delivery, and perinatal period of the patient had been uneventful. He was an inactive baby with delayed motor development, walking with a broadly based ataxic gait from the age of 3 years. His mental development was retarded. At the age of 23 and 36 months his scores on the Denver test were 12 and 24 months, respectively. At the age of 3.9 years he was dysarthric with a slow and monotonous speech and hoarse and soft voice. Complex movements of mouth and tongue were disturbed. Eye movements were full, but saccadic and there was no nystagmus. Optic discs were pale and vision was moderately impaired. In addition mild spasticity and ataxia were present in all extremities. At the age of 8.6 years neurological examination was unchanged and he attended a school for physically disabled children. Mental handicap was moderately severe: WISC-RN IQ 55-59 (verbal IQ 68-79, performal IQ 45-49). From the age of 10 years vision started to deteriorate due to progressive optic atrophy. His speech became unintelligible and truncal ataxia as well as ataxia and spasticity of extremities progressively increased until he was wheelchair bound and helpless at the age of 15 years. At 13 years of age frequent tonic-clonic epileptic seizures occurred, which were controlled with lamotrigine monotherapy.

CT scan at the age of 4 years was normal. Brain MRI taken at 5.3, 8.6, and 12.6 years of age all showed the same severe abnormalities of myelination. On Tl weighted images, high signal intensity was only present in the white matter of the brainstem, cerebellum, optic radiation, and internal capsule. On T2 weighted and inversion recovery images, there was nearly complete absence of low signal intensity in the supratentorial white matter (fig 1). Proton MRS at the age of 11.7 years (CSI 135 and $40 \mathrm{~ms}$ ) showed normal concentrations of $\mathrm{N}$-acetyl aspartate, choline, and creatine levels in 48 white and grey matter $2 \mathrm{ml}$ voxels (TR $135 \mathrm{~ms}$, TE $40 \mathrm{~ms}$ ).

Neurophysiological studies showed severe postchiasmatic slowing of the visual evoked responses on both sides and severe slowing of the brainstem auditory evoked responses, with normal sensitivity of both ears to sounds. Sensory and motor nerve conduction studies at 3.10 and 9.3 years of age were normal. MRI abnormalities are identical to those described in Pelizaeus-Merzbacher disease (PMD), showing severe dysmyelination without evidence of myelin destruction. ${ }^{15} 16$ No involvement of the peripheral nervous system could be demonstrated. Development in our patient slowly progressed until the age of 10 years. At that age regression started and from the age of 15 years onwards he neurologically deteriorated quite rapidly.

\section{Analysis of the $\mathrm{X}$ chromosomal breakpoint regions}

Cytogenetically, both the patient and his unaffected mother presented an apparently balanced inverted X chromosome
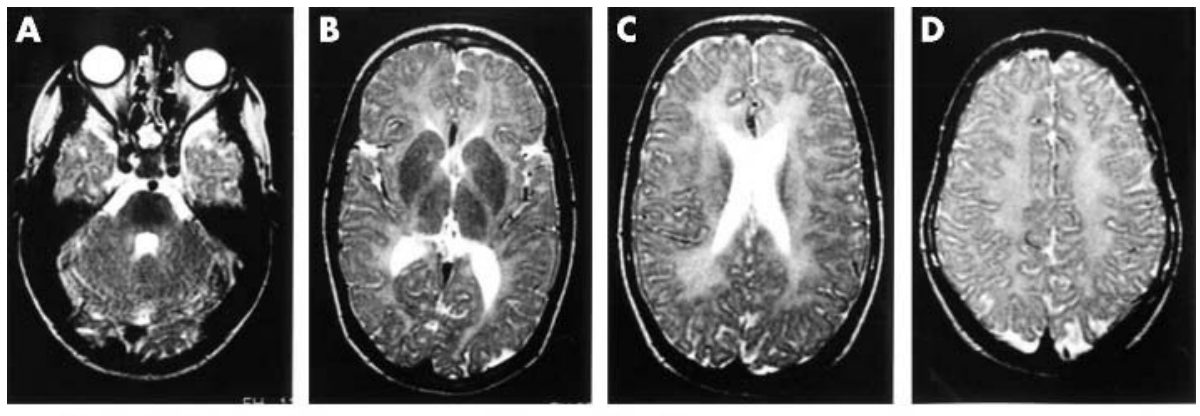

Figure 1 Axial T2 weighted NMR images at the age of 6.3 years (A-D) and 9.3 years $(\mathrm{E}-\mathrm{H})$. The characteristic hypointense signals indicating the presence of myelinated fibres are absent in the pons and the medial cerebellar peduncles ( $A$ and $E$ ) and in the internal capsules ( $B$ and $F$ ) and are sparse in the basal areas of the corona radiata ( $\mathrm{B}-\mathrm{D}$ and $\mathrm{F}-\mathrm{H})$. This pattern remained the same from 6.3 to 9.3 years of age. In addition, no brain atrophy is present.
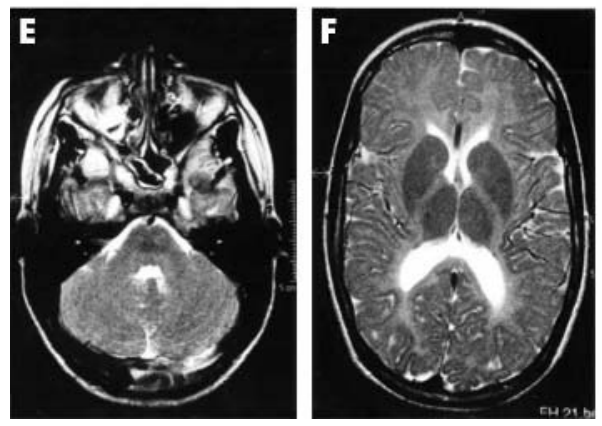

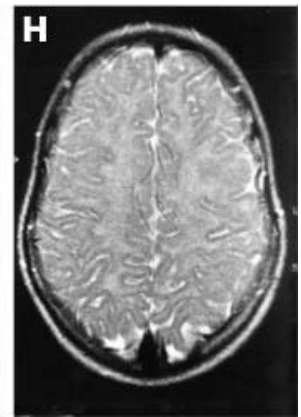


Table 1 Clinical presentation of connatal and classic type PMD versus the analysed patient

\begin{tabular}{|c|c|c|c|}
\hline \multirow[b]{2}{*}{ Symptoms } & \multicolumn{2}{|l|}{ PMD type } & \multirow[b]{2}{*}{ Patient } \\
\hline & Connatal & Classic & \\
\hline Nystagmus & + & + & - \\
\hline Stridor & + & + & - \\
\hline "Head bobbing" & + & + & - \\
\hline $\begin{array}{l}\text { Developmental } \\
\text { delay }\end{array}$ & + & + & + \\
\hline $\begin{array}{l}\text { Developmental } \\
\text { deterioration }\end{array}$ & $\sim 3$ months & $\sim 4$ years & $\sim 10$ years \\
\hline Optic atrophy & + & + & + \\
\hline $\begin{array}{l}\text { Extrapyramidal } \\
\text { movements }\end{array}$ & + & + & $+1-$ \\
\hline Spasticity & + & + & + \\
\hline Ataxia & + & + & + \\
\hline Epilepsy & $+1-$ & - & + \\
\hline VEP & Abnormal & Abnormal & Abnormal \\
\hline BAER & Abnormal & Abnormal & Abnormal \\
\hline NMR & $\begin{array}{l}\text { Severe } \\
\text { dysmyelination, } \\
\text { progressive } \\
\text { cortical atrophy }\end{array}$ & $\begin{array}{l}\text { Severe } \\
\text { dysmyelination, } \\
\text { progressive } \\
\text { cortical atrophy }\end{array}$ & $\begin{array}{l}\text { Severe } \\
\text { dysmyelination, } \\
\text { no cortical } \\
\text { atrophy }\end{array}$ \\
\hline
\end{tabular}

BAER, brainstem auditory evoked responses; NMR, nuclear magnetic resonance; VEP, visual evoked potential.

with the breakpoints in Xp22 and Xq22 (fig 2A). To characterise the breakpoint regions in more detail, fluorescence in situ hybridisation (FISH) analysis was carried out. As regards the breakpoint region in Xp22, Rao and colleagues $^{17}$ had previously shown that the breakpoint on the short arm of the X chromosome is close to the SHOX gene in the pseudoautosomal region, but does not interrupt the gene. As the patient's unaffected mother shows the identical $\mathrm{X}$ chromosomal rearrangement, the breakpoint within the pseudoautosomal region is not causative for the phenotype of the patient. Therefore, the second breakpoint in Xq22, which can not be compensated for in the male patient, is likely to be involved in the pathology.

The YAC clone CEPHy904G09923 was shown by in situ hybridisation to span the breakpoint in Xq22. This clone contains the PLPI gene, encoding the proteolipid protein, a major constituent of myelin sheaths. To further narrow down the breakpoint region, a progressive hierarchy of YAC, PAC, and cosmid clones covering the region of CEPHy904G09223 was used for FISH analysis on metaphase spreads of the patient. ${ }^{18}$ We can show that the PAC clone RPCIP7041055C14 (insert size $100 \mathrm{~kb}$ ) bridges the breakpoint (fig 2B). Using EcoRV fragments from this PAC as FISH probes, we were able to demonstrate that the breakpoint lies in the genomic region of the GLRA4 gene. GLRA4 encodes a gene with high homology to the human glycine receptor subunit GLRA2 and the murine glra4 and is approximately $70 \mathrm{~kb}$ away from the PLPI gene (fig $2 \mathrm{C}$ ). Southern blot analysis mapped the breakpoint between exons 8 and 9 of GLRA4 (data not shown).

\section{Possible implications of GLRA4 and PLP1 in patients} with ataxia, dysmyelination, or spastic paraplegia Although we could show expression of GLRA4 by using reverse transcription polymerase chain reaction (RT-PCR) in adult and fetal brain (data not shown), we considered it to be a pseudogene as the gene encodes a truncated protein lacking a fourth transmembranic domain typical for other glycine receptor subunits. To analyse whether the interruption of GLRA4 nevertheless contributes to the pathogenesis or whether a position effect on PLPl is the more likely reason for the phenotype, we investigated the DNA samples of an additional 24 patients. These patients presented with ataxia and a hypomyelinisation pattern comparable with that seen in PMD patients, and displayed a clinical phenotype similar to that of the patient with the inverted $X$ chromosome, but did not have a duplication or mutation within the PLPI gene. We performed SSCP analysis on the genomic DNA of nine patients with isolated ataxia and dysmyelination followed by sequencing, but we did not find any gene variations. We also screened 15 patients with isolated ataxia for mutations in GLRA4. However, no change in SSCP pattern was observed. Spastic paraplegia has been shown to be allelic to PMD in some entities, ${ }^{67}$ although there are families with spastic paraplegia and linkage to $\mathrm{Xq} 22$, but no mutation in the PLPI
A
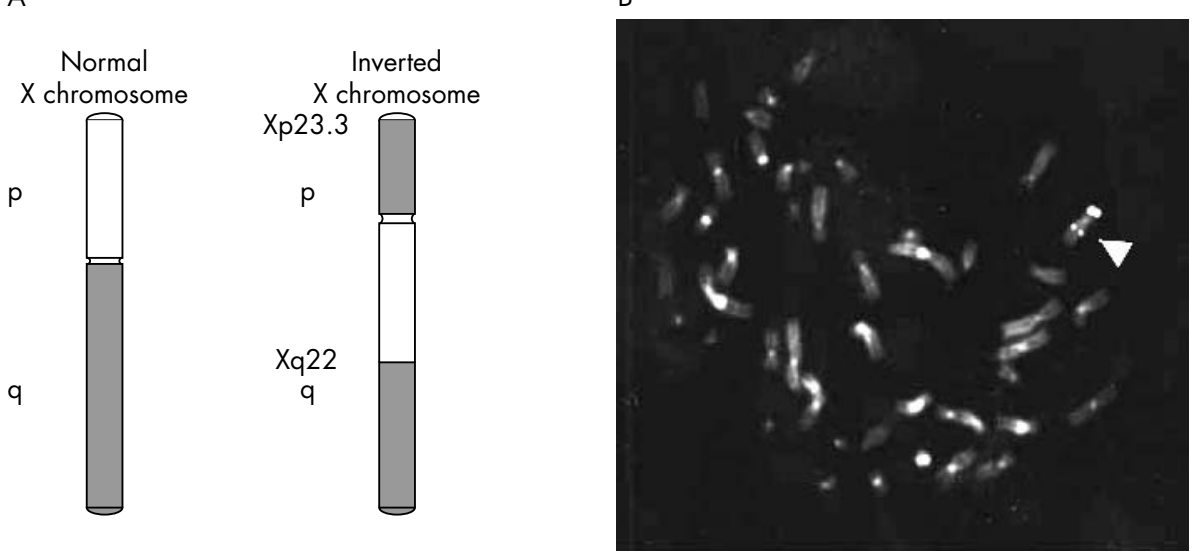

Figure 2 (A) Schematic representation of the normal (left) versus the inverted (right) $\mathrm{X}$ chromosome. For better visibility the short and long arms of the chromosomes are shaded differently. The Xp22.3 region at the tip of $X p$ is not drawn to scale. (B) FISH of PAC RPCIP7041055C14 to metaphase spreads of the patient. The PAC spans the breakpoint in the patient (white arrowhead). (C) Scheme showing orientation and distance between PLPI and GLRA4, and localisation of the breakpoint $5^{\prime}$ of $P L P 1$. Distances and genes are not drawn to scale.

C

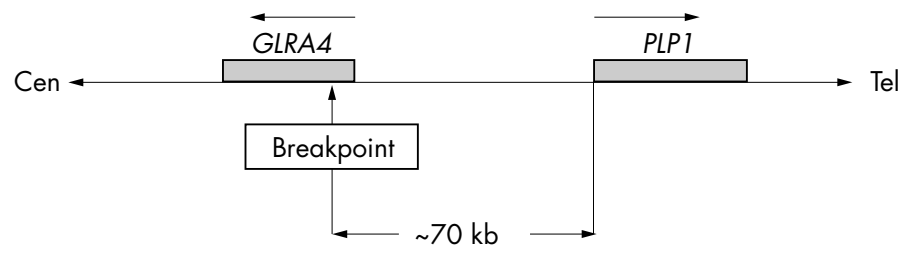


gene. ${ }^{19}$ We analysed two members of the reported family with spastic paraplegia ${ }^{19}$ by sequencing the coding region of GLRA4. At position 555 of the cDNA a $\mathrm{C}$ to $\mathrm{G}$ transition was detected. Analysis of unrelated controls identified this change as a frequent polymorphism that occurs in approximately $40-50 \%$ of all individuals tested.

As we did not consider GLRA4 to be causative in the patients with an inverted $X$ chromosome, we addressed the possibility that the PLPI gene itself, which is located only $70 \mathrm{~kb}$ away, was affected (fig 2C). However, metaphase as well as interphase FISH analysis using a cosmid containing PLP1 revealed no inversion, deletion, or duplication. Nor did fine mapping PCRs reveal any aberration. Sequencing of the entire coding region of PLPI did not show any nucleotide alteration. Therefore, the most likely mechanism underlying the specific and PMD related phenotype in this patient is a position effect due to the close proximity of the PLPI gene.

\section{DISCUSSION}

PMD is a rare X linked central nervous system leukodystrophy characterised by dysmyelination of the CNS with key clinical features of early onset nystagmus and hypotonia and, depending on whether the clinical type is either connatal or classic, relatively rapid or slow progression of cerebellar, pyramidal, extrapyramidal, and cognitive symptoms. ${ }^{12}$ Additionally, cerebellar ataxia and mental retardation can be observed in some patients. Point mutations in PLP1 have been detected in $10-25 \%$ of PMD patients, but duplications of the gene account for the majority of cases. ${ }^{9}{ }^{10} 2021$ Deletions of $P L P I^{22}{ }^{23}$ and splice site ${ }^{24}$ and intronic region mutations ${ }^{25}$ have also been described. In $10-20 \%$ of patients there is no detectable duplication or mutation within the PLPI gene. Patients with a duplication commonly exhibit a milder PMD phenotype than those with missense or other mutations. However, much of the clinical variability is not yet understood. Gene dosage of PLP1, possibly also affected by modifier genes either within the duplicated region or elsewhere in the genome, seems to be critical as regards the phenotype. ${ }^{8627}$

We have analysed the breakpoints of an X inversion in a patient with a subset of PMD symptoms. One breakpoint, in the pseudoautosomal region, could be excluded as the unaffected mother carries the same inversion. ${ }^{17}$ The breakpoint in Xq22 disrupts the genomic sequence of GLRA4, encoding a putative glycine receptor $\alpha$ subunit. Variants of such ligand binding $\alpha$ and structural $\beta$ subunits form different isoforms of the glycine receptor. ${ }^{28}{ }^{29}$ These subunits share a similar membrane topology with a large extracellular $\mathrm{N}$-terminal domain being followed by four membrane spanning segments. Mutations in several of the corresponding genes, both in humans and mice, have been involved in neurological disorders such as hypereklexia. ${ }^{30-32}$ However, unlike the other human glycine receptor subunit genes, GLRA4 harbours a premature stop codon within exon 9, leading to the translation of only three transmembrane domains. As such a subunit is unlikely to form a functional receptor, we support the classification of GLRA4 as a pseudogene as annotated in the, NCBI database (AL049610). More evidence that the fourth transmembrane domain is crucial for receptor function and that GLRA4 therefore is a non-functional pseudogene, also comes from studies of the oscillator mouse. ${ }^{31}$ A microdeletion in the gene coding for the al subunit (Glral), resulting in the loss of a cytoplasmic loop and the fourth transmembrane domain, leads to a $90 \%$ reduction in binding affinity of the receptor, resembling a complete loss of function allele. ${ }^{31}$ It is therefore unlikely that the gene interruption contributes to the pathogenesis of our patient. This idea is also supported by the fact that we could not find any patient specific mutations. Although we are aware that the number of analysed patients is limited and that we can not definitely rule out a putative role for GLRA4 as a modifier gene as it is situated in the duplication fragment of some patients and could therefore contribute to the wide variations of the PMD phenotype, we do not consider it causative with respect to the dysmyelination defect seen in our patient. The main clinical features can rather be explained by a positional effect on the nearby PLPI gene.

Position effects have been described for a number of genetic diseases ${ }^{33}$ and are thought to influence the expression pattern of the affected genes. Distances between breakpoints and affected genes can range from $3 \mathrm{~kb}$ as shown for $S R Y^{34}{ }^{35}$ to over $1 \mathrm{Mb}$ in the case of $S O X 9 .{ }^{36}$ In our case one could speculate that the breakpoint may put the gene under different regulatory constraints leading to a changed expression pattern, which would alter developmental pathways in only some tissues affected in PMD and not in others. This could explain why the patient with an inverted $X$ chromosome displays only a subset of symptoms. Another possibility would be that the degree of expression is varied: as PLPI silencing is expected to lead to a very different phenotype, ${ }^{12}$ the most likely explanation is that its expression will be increased, mimicking rather a duplication of the gene. This might explain the high degree of similarity between PMD patients carrying a PLP duplication and the inversion patient. Our findings underline once more that gene dosage of PLPI seems to be the crucial factor in the pathology of the variable phenotypes.

\section{ACKNOWLEDGEMENTS}

We would like to thank R Steinmüller and U Müller for providing the DNA of a patient with SPG2 for mutation analysis.

\section{Authors' affiliations}

N Muncke, B S Wogatzky, V Endris, G Rappold, Institute of Human Genetics, Ruprecht-Karls-University, Im Neuenheimer Feld 366, 69120 Heidelberg, Germany

M Breuning, Department of Human Genetics, Wassenaarseweg 72, PO Box 9503, 2300 RA Leiden, The Netherlands

E A Sistermans, Department of Human Genetics, University Medical Center Nijmegen, PO Box 9101, 6500 HB Nijmegen, The Netherlands M Ross, D Vetrie, The Sanger Centre, X Chromosome Mapping Group, Wellcome Trust Genome Campus, Hinxton, Cambridge CB10 1SA, UK C E Catsman-Berrevoets, Department of Child Neurology, Erasmus MC/ Sophia Children's Hospital, Dr. Molewaterplein 60, 3015 GJ Rotterdam, The Netherlands

This work was supported by the Bundesministerium für Bildung und Forschung. NM was supported by the Landesgraduiertenförderung of Baden-Württemberg, Germany.

Conflict of interest: none declared.

*The first two authors contributed equally to this study.

Correspondence to: Professor Gudrun Rappold, Institute of Human Genetics, Im Neuenheimer Feld 366, 69120 Heidelberg, Germany; gudrun_rappold@med.uni-heidelberg.de

Revised version received 28 June 2004

Accepted for publication 2 July 2004

\section{REFERENCES}

1 Pelizaeus, F. Ueber eine eigentuemliche Form spastischer Laehmung mit Cerebralerscheinungen auf hereditaerer Grundlage (multiple Sklerose). Arch Psychiat Nervenkr 1885; 16:698.

2 Merzbacher L. Gesetzmaessigkeiten in der Vererbung und Verbreitung verschiedener hereditaerer-familiaerer Erkrankungen. Arch Rass Ges Biol 1909;6:172-98.

3 Koeppen AH, Robitaille Y. Pelizaeus-Merzbacher disease. J Neuropathol Exp Neurol 2002;61:747-59.

4 Hudson LD, Puckett C, Berndt J, Chan J, Gencic S. Mutation of the proteolipid protein gene PLP in a human X chromosome-linked myelin disorder. Proc Natl Acad Sci U S A 1989;86:8128-31. 
5 Hodes ME, Pratt VM, Dlouhy SR. Genetics of Pelizaeus-Merzbacher disease. Dev Neurosci 1993; 15:383-94.

6 Saugier-Veber P, Munnich A, Bonneau D, Rozet J-M, Le Merrer M, Gil R, Boespflug-Tanguy $O$. X-linked spastic paraplegia and Pelizaeus-Merzbacher disease are allelic disorders at the proteolipid protein locus. Nat Genet 1994;6:257-61

7 Cambi F, Tang X-M, Cordray P, Fain PR, Keppen LD, Barker DF. Refined genetic mapping and proteolipid protein mutation analysis in X-linked pure hereditary spastic paraplegia. Neurology 1996;46:1112-7.

8 Woodward K, Malcolm S. CNS myelination and PLP gene dosage. Pharmacogenomics 2001;2:263-72.

9 Woodward K, Kendall E, Vetrie D, Malcolm S. Pelizaeus-Merzbacher disease: identification of $\mathrm{Xq} 22$ proteolipid-protein duplications and characterization of breakpoints by interphase FISH. Am J Hum Genet 1998;63:207-17

10 Inoue K, Osaka H, Thurston VC, Clarke JT, Yoneyama A, Rosenbarker L, Bird TD, Hodes ME, Shaffer LG, Lupski JR. Genomic rearrangements resulting in PLP1 deletion occur by nonhomologous end joining and cause different dysmyelinating phenotypes in males and females. Am J Hum Genet 2002;71:838-53.

11 Sistermans EA, de Wijs IJ, de Coo RF, Smit LM, Menko FH, van Oost BA. A (G-to-A) mutation in the initiation codon of the proteolipid protein gene causing a relatively mild form of Pelizaeus-Merzbacher disease in a Dutch family. Hum Genet 1996;97:337-9.

12 Garbern JY, Yool DA, Moore GJ, Wilds IB, Faulk MW, Klugmann M, Nave KA, Sistermans EA, van der Knaap MS, Bird TD, Shy ME, Kamholz JA, Griffiths IR. Patients lacking the major CNS myelin protein, proteolipid protein 1 , develop length-dependent axonal degeneration in the absence of demyelination and inflammation. Brain 2002;125(pt 3):551-61.

13 Lichter P, Cremer T. Human cytogenetics: a practical approach. Oxford: IRL/ Oxford University Press, 1992.

14 Orita M, Suzuki Y, Sekiya T, Hayashi K. Rapid and sensitive detection of point mutations and polymorphisms using the polymerase chain reaction. Genomics 1989:5:874-9.

15 Van der Knaap MS, Valk J. The reflection of histology in MR imaging of Pelizaeus-Merzbacher disease. Am J Neuroradiol 1989;10:99-103.

16 Scheffer IE, Baraitser M, Wilson J. Pelizaeus-Merzbacher disease: classical or connatal? Neuropediatrics 1991;10:71-8.

17 Rao E, Weiss B, Fukami M, Rump A, Niesler B, Mertz A, Muroya K, Binder G Kirsch S, Winkelmann M, Nordsiek G, Heinrich U, Breuning MH, Ranke MB, Rosenthal A, Ogata T, Rappold GA. Pseudoautosomal deletions encompassing a novel homeobox gene cause growth failure in idiopathic short stature and Turner syndrome. Nat Genet 1997:16:54-63.

18 Vetrie D, Kendall E, Coffey A, Hassock S, Collins J, Todd C, Lehrach H, Bobrow M, Bentley DR, Harris A. A 6.5-Mb yeast artificial chromosome contig incorporating 33 DNA markers on the human $\mathrm{X}$ chromosome at $\mathrm{Xq} 22$. Genomics 1994:19:42-7.

19 Steinmüller R, Lantigua-Cruz A, Garcia-Garcia R, Kostrzewa M,

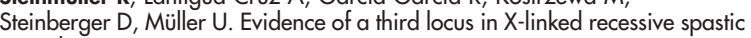
paraplegia. Hum Genet 1997; 100:287-9.

20 Hodes ME, Dlouhy SR. The proteolipid protein gene: double, double, and trouble. Am J Hum Genet 1996;59:12-5.
21 Sistermans EA de Coo RFM, de Wiis IJ, Van Oost BA. Duplication of the proteolipid protein gene is the major cause of Pelizaeus-Merzbacher disease. Neurology 1998; 50:1749-54

22 Raskind WH, Williams CA, Hudson LD, Bird TD. Complete deletion of the proteolipid protein gene (PLP) in a family with X-linked Pelizaeus-Merzbacher disease. Am J Hum Genet 1991;49:1355-60.

23 Inoue K, Osaka H, Imaizumi K, Nezu A, Takanashi J, Arii J, Murayama K, Ono J, Kikawa Y, Mito T, Shaffer LG, Lupski JR. Proteolipid protein gene duplications causing Pelizaeus-Merzbacher disease: molecular mechanism and phenotypic manifestations. Ann Neurol 1999:45:624-32.

24 Strautnieks S, Malcolm S. A G to T mutation at a splice site in a case of Pelizaeus-Merzbacher disease. Hum Mol Genet 1993;2:2191-2.

25 Hobson GM, Davis AP, Stowell NC, Kolodny EH, Sistermans EA, de Coo IF Funanage VL, Marks HG. Mutations in noncoding regions of the proteolipid protein gene in Pelizaeus-Merzbacher disease. Neurology 2000;55:1089-96.

26 Hodes ME, Zimmerman AW, Aydanian A, Naidu S, Miller NR, Oller JLG, Barker B, Aleck KA, Hurley TD, Dlouhy SR. Different mutations in the same codon of the proteolipid protein gene, PLP, may help in correlating genotype with phenotype in Pelizaeus-Merzbacher disease/X-linked spastic paraplegia (PMD/SPG2). Am J Med Genet 1999;82:132-9.

27 Woodward K, Malcolm S. Pelizaeus-Merzbacher disease in humans and neurodegeneration in mice. Trends Genet 1999;15:125-8.

28 Betz H. Structure and function of inhibitory glycine receptor. Q Rev Biophys 1992;25:381-94.

29 Becker C-M. Glycine receptors: molecular heterogeneity and implications for disease. Neuroscientist 1995; 1:130-41.

30 Shiang R, Ryan SG, Zhu Y-Z, Hahn AF, O'Connell P, Wasmuth JJ. Mutations in the alpha 1 subunit of the inhibitory glycine receptor cause the dominant neurologic disorder, hypereklexia. Nat Genet 1993;5:351-7.

31 Buckwalter MS, Cook SA, Davisson MT, White WF, Camper S. A frameshift mutation in the mouse alpha 1 glycine receptor gene (Glral) results in progressive neurological symptoms and juvenile death. Hum Mol Genet 1994:3:2025-30

32 Ryan SG, Buckwalter MS, Lynch JW, Handford CA, Segura L, Shiang R, Wasmuth JJ, Camper SA, Schofield P, O'Connell P. A missense mutation in the gene encoding the alpha 1 subunit of the inhibitory glycine receptor in the spasmodic mouse. Nat Genet 1994;7:131-5.

33 Kleinjan DJ, van Heyningen V. Position effect in human genetic disease. Hum Mol Genet 1998;7:161 1-8.

34 McElreavey K, Vilain E, Abbas N, Costa JM, Souleyreau N, Kucheria K, Boucekkine C, Thibaud E, Brauner R, Flamant F, Fellous N. XY sex reversal associated with a deletion 5 ' to the SRY ' $\mathrm{HMG}^{\prime}$ ' box in the testis determining region. Proc Natl Acad Sci U S A 1992;89:11016-20.

35 McElreavey K, Vilain E, Barbaux S, Fuqua JS, Fechner PY, Souleyreau N, Doco-Fenzy M, Gabriel R, Quereux C, Fellous M, Berkovitz GD. Loss of sequences $3^{\prime}$ to the testis-determining gene, SRY, including the $Y$ pseudoautosomal boundary associated with partial testicular determination. Proc Natl Acad Sci U S A 1996;93:8590-4.

36 Pfeifer D, Kist R, Dewar K, Devon K, Lander ES, Birren B, Korniszewski L, Back E, Scherer G. Campomelic dysplasia translocation breakpoints are scattered over $1 \mathrm{Mb}$ proximal to SOX9: evidence for an extended control region. Am J Hum Genet 1999;65:111-24. 